\title{
Płynność finansowa przedsiębiorstw rolniczych w Polsce (na przykładzie uczestników „Rankingu 300”)
}

\section{Wstęp}

Problematyka płynności finansowej w przedsiębiorstwach rolniczych wywołuje wiele dyskusji, ponieważ nie zostało dotychczas jednoznacznie stwierdzone, jakie poziomy wskaźników należałoby rekomendować grupie przedsiębiorstw. Często podnosi się kwestię poziomu zapasów, który w przedsiębiorstwach rolniczych jest wysoki, i niskich poziomów zobowiązań, które również stanowią o specyfice zarządzania kapitałem obrotowym w tej grupie podmiotów. Interesujący zatem pozostaje nadal problem poziomów wskaźników płynności, szczególnie w grupie przedsiębiorstw rolniczych, które zwyczajowo określa się mianem „najlepszych przedsiębiorstw rolniczych”.

\section{Cel i metodyka badań}

Celem badań była ocena sytuacji finansowej oraz płynności finansowej przedsiębiorstw rolniczych w Polsce. Badania dotyczyły przedsiębiorstw uczestniczących w „Rankingu 300” organizowanym przez zespół pracowników Instytutu Ekonomiki Rolnictwa i Gospodarki Żywnościowej - Państwowego Instytutu Badawczego (IERIGŻ-PIB) od połowy lat 90. XX wieku. Na podstawie opublikowanych przez IERIGŻ-PIB danych przygotowano bazę danych, wybierając do badania przedsiębiorstwa z czołówki (50 przedsiębiorstw, co stanowi 17. percentyl) i z końcówki zestawienia (50 przedsiębiorstw, co dało 83. percentyl) „Rankingu 300”. Takie badanie ma na celu sprawdzenie czy przedsiębior- 
stwa z czołówki oraz końcówki zestawienia różnią się w uzyskiwanych wynikach finansowych (w ostatnich latach, w rankingu są usystematyzowane według wskaźnika syntetycznego). Do oceny sytuacji finansowej wybrano poziom przychodów, wskaźnik pokrycia aktywów kapitałem własnym oraz poziom pokrycia zobowiązań nadwyżką finansowa. Aby ocenić płynność finansową zastosowano wskaźniki płynności bieżącej, płynności szybkiej oraz zdolności do generowania gotówki operacyjnej. Obliczenia wykonano w programie Statistica 10 oraz Excel.

Aby ocenić zasoby badanych grup przedsiębiorstw zestawiono ze sobą informacje o poziomie powierzchni użytków rolnych, poziomie przeciętnego zatrudnienia oraz wskaźnikach bonitacji gleb (tab. 1). Stwierdzono, że przedsiębiorstwa z czołówki rankingu gospodarowały na mniejszej powierzchni niż przedsiębiorstwa z końcówki (poza 2009 r.). Zasadniczo różnica między grupami przedsiębiorstw w powierzchni użytków rolnych liczyła ok. 300 ha. Przedsiębiorstwa $\mathrm{z}$ czołówki rankingu systematycznie powiększały powierzchnię swoich użytków rolnych, te z końcówki zestawienia gospodarowały natomiast na mniej więcej takim samym areale (chociaż zmieniającym swoje parametry w badanym okresie).

Podobnie prezentowała się sytuacja w wypadku liczby zatrudnionych przeciętnie w ciagu roku. Przedsiębiorstwa z pierwszej 50 zestawienia zatrudniały przeciętnie znacznie mniejszą liczbę osób niż przedsiębiorstwa z ostatniej 50. Przeciętnie stan zatrudnionych w pierwszej grupie wahał się między niespełna

\section{Tabela 1}

Wybrane miary charakteryzujące przedsiębiorstwa rolnicze uczestniczące w „Rankingu 300" w latach 2007-2012 (17. i 83. percentyl)

\begin{tabular}{|c|c|c|c|c|c|c|}
\hline \multirow{2}{*}{ Wyszczególnienie } & \multicolumn{7}{c|}{ Dane w latach } \\
\cline { 2 - 7 } & 2007 & 2008 & 2009 & 2010 & 2011 & 2012 \\
\hline \multicolumn{7}{|c|}{ Powierzchnia użytków rolnych [ha UR] } \\
\hline Przedsięb. - 17. percentyl & 691,26 & 662,64 & 1086,28 & 749,18 & 743,92 & 750,60 \\
\hline Przedsięb. - 83. percentyl & 1081,88 & 1243,40 & 870,56 & 1113,82 & 965,64 & 1021,28 \\
\hline \multicolumn{7}{|c|}{ Liczba zatrudnionych przeciętnie w ciagu roku } \\
\hline Przedsięb. - 17. percentyl & 17,32 & 19,30 & 29,20 & 15,08 & 14,96 & 13,60 \\
\hline Przedsięb. - 83. percentyl & 60,38 & 53,68 & 46,31 & 43,31 & 37,37 & 50,50 \\
\hline \multicolumn{7}{|c|}{ Wskaźnik bonitacji gleb } \\
\hline Przedsięb. - 17. percentyl & 1,15 & 1,12 & 1,06 & 1,11 & 1,19 & 1,15 \\
\hline Przedsięb. - 83. percentyl & 0,94 & 0,99 & 1,06 & 1,00 & 1,01 & 1,08 \\
\hline
\end{tabular}

Źródło: Opracowanie własne na podstawie danych „Rankingu 300” za lata 2007-2012, https://www.ierigz.waw.pl/prace-badawcze/ranking-300 (data dostępu: 29.07.2014). 
14-30 osobami, a w drugiej grupie między niespełna 38-61 osobami. Różnice były więc znaczące. Różnice $\mathrm{w}$ poziomie zatrudnienia w części są konsekwencją tego, że przedsiębiorstwa z czołówki były mniejsze (gospodarowano na mniejszej powierzchni użytków rolnych). Pewne różnice zaobserwowano również w jakości ziemi, na której prowadzona była działalność gospodarcza badanych grup przedsiębiorstw. Przedsiębiorstwa z czołówki zestawienia cechowały się nieco wyższymi wskaźnikami bonitacji gleb we wszystkich analizowanych latach (jedynie w 2008 r. wskaźnik bonitacji był taki sam w obu badanych grupach przedsiębiorstw), co dawało potencjalnie większe możliwości uzyskania wyższych efektów gospodarowania.

W uogólnieniu stwierdzono więc, że przedsiębiorstwa z czołówki „Rankingu 300" były mniejsze, przyjmując za miarę powierzchnię użytków rolnych i przeciętną liczbę zatrudnionych, ale pozostawały w posiadaniu ziemi lepszej jakości (mierzonej współczynnikiem bonitacji gleb). Różnice między prezentowanymi miarami w badanych grupach przedsiębiorstw były dość znaczne, chociaż zmienne w kolejnych latach.

\section{Problematyka płynności finansowej w literaturze}

Jak wynika z badań Franc-Dąbrowskiej, płynność finansowa jest zagadnieniem złożonym i niejednoznacznym, definiowanym w sposób różnorodny, a zarządzanie płynnością finansową przedsiębiorstw rolniczych powinno uwzględniać historyczny i kulturowy kontekst [Franc-Dąbrowska 2011, s. 10]. Podobne spostrzeżenia - zwracając uwagę na to, że interpretacja wskaźników płynności przedsiębiorstw rolniczych pozostaje kwestią sporną - poczynili Zawadzka i inni [2011, s. 195]. Płynność finansowa badana jest w wielu jej aspektach. Jednym z istotnych obszarów analiz jest poziom i zmienność kapitału obrotowego. Takie badania na grupie gospodarstw rolniczych prowadziła Bereżnicka, z której obliczeń wynika, że w latach 2004-2008 wskaźniki płynności bieżącej były na wyższym poziomie niż wielkości znane z literatury, jednak wskaźniki płynności szybkiej były nieco wyższe lub zbliżone do poziomu 1, przy czym były to wielkości charakteryzujące gospodarstwa $\mathrm{z}$ dolnego kwartyla (te z górnego cechowały się wskaźnikami płynności szybkiej na bardzo wysokich poziomach) [Bereżnicka 2011, s. 52].

Z badań wskaźników płynności bieżącej i szybkiej w gospodarstwach rolnych w Unii Europejskiej prowadzonych przez Bieniasz i Gołasia wynika, że występuje bardzo wyraźne zróżnicowanie w poziomie wskaźników w zależności od kraju. Najwyższymi poziomami płynności finansowej cechowały się takie kraje, jak Belgia, Hiszpania, Włochy, Grecja i Portugalia, najniższymi natomiast 
Niemcy, Dania, Szwecja i Wielka Brytania [Bieniasz i Gołaś 2006, s. 28-29]. Podobne spostrzeżenia poczynili Mańko i inni, którzy zwrócili również uwagę na znaczne zróżnicowanie, a także różnokierunkowość zmian poziomu wskaźników płynności w różnych krajach [Mańko i in. 2008, s. 5-22].

Interesujące podejście - badając płynność gospodarstw sadowniczych - zastosował Paszko, który analizował płynność finansowa, oceniając przepływy z działalności operacyjnej wyłącznie na podstawie ich oceny, ustalając czy gospodarstwa cechowały się płynnością finansowa, czy też nie [Paszko 2010, s. 204 -205]. W ocenie autorki jest to zbyt uproszczone podejście, jednak dające dobry pogląd na to czy podstawowa działalność gospodarcza gwarantuje przedsiębiorcom uzyskanie dodatnich efektów gotówkowych, czy też wymaga wspomagania środkami pieniężnymi z obszaru działalności inwestycyjnej i finansowej.

$\mathrm{Z}$ badań gospodarstw ogrodniczych w krajach Unii Europejskiej, które prowadziła Stefko, wynika, że także i ta grupa producentów charakteryzuje się znacznym zróżnicowaniem poziomów wskaźników płynności bieżącej i szybkiej w zależności od kraju. W latach 2004-2008 najwyższe poziomy wskaźników cechowały Hiszpanię, najniższe natomiast Estonię. Różnice były ponadstukrotne [Stefko 2011, s. 148].

$\mathrm{Z}$ badań Szafraniec-Siluty dotyczących bezpieczeństwa finansowego przedsiębiorstw rolniczych wynika, że przedsiębiorstwa rolnicze (średnio w latach 2006-2011) osiagnęły wyższy poziom wskaźnika płynności długoterminowej, który określa bezpieczeństwo finansowe, niż przedsiębiorstwa ogółem [Szafraniec-Siluta 2013, s. 414]. Z kolei Wasilewski i Gałecka, badając gospodarstwa rolnicze w województwie lubelskim, stwierdzili zróżnicowanie wskaźników płynności finansowej w zależności od typu prowadzonej działalności.

Wszystkie przytoczone wyniki badań potwierdzają złożoność oceny płynności w przedsiębiorstwach rolniczych. Bez wątpienia jest to obszar intrygujących analiz, które - być może w przyszłości - umożliwią ustalenie określonych zakresów płynności, które można byłoby jednoznacznie dedykować konkretnym grupom przedsiębiorstw.

\section{Wyniki badań i dyskusja}

W celu zbadania sytuacji finansowej, umożliwiającej pogląd na badane przedsiębiorstwa i odniesienie do płynności finansowej, w tabeli 2 przedstawiono wybrane miary finansowe, takie jak przychody ze sprzedaży, poziom finansowania aktywów kapitałem własnym oraz poziom pokrycia zobowiązań nadwyżką finansową. Stwierdzono znaczne różnice między badanymi grupami przedsiębiorstw. Jednostki z czołówki zestawienia cechowały się wyraźnie niższym poziomem 
Tabela 2

Wybrane miary sytuacji finansowej przedsiębiorstw rolniczych uczestniczących w „Rankingu 300" w latach 2007-2012 (17. i 83. percentyl)

\begin{tabular}{|c|c|c|c|c|c|c|}
\hline \multirow{2}{*}{ Wyszczególnienie } & \multicolumn{7}{|c|}{ Dane w latach } \\
\cline { 2 - 7 } & 2007 & 2008 & 2009 & 2010 & 2011 & 2012 \\
\hline \multicolumn{7}{|c|}{ Przychody [tys. zł] } \\
\hline Przedsięb.- 17. percentyl & 4096,3 & 4556,3 & 9931,0 & 4835,1 & 5338,8 & 6405,3 \\
\hline Przedsięb. - 83. percentyl & 10490,9 & 12839,2 & 13514,7 & 15545,0 & 13033,4 & 12840,1 \\
\hline \multicolumn{7}{|c|}{ Poziom finansowania aktywów kapitałem własnym (\%) } \\
\hline Przedsięb. - 17. percentyl & 64,88 & 74,98 & 70,09 & 72,74 & 76,11 & 75,08 \\
\hline Przedsięb. - 83. percentyl & 72,12 & 65,04 & 61,55 & 65,27 & 66,88 & 74,73 \\
\hline Poziom pokrycia zobowiązań nadwyżką finansową \\
\hline Przedsięb. - 17. percentyl & 2,19 & 2,57 & 1,64 & 2,47 & 6,33 & 4,04 \\
\hline Przedsięb. - 83. percentyl & 0,89 & 0,35 & 0,35 & 0,53 & 0,48 & 0,87 \\
\hline
\end{tabular}

Źródło: Opracowanie własne na podstawie danych „Rankingu 300” za lata 2007-2012, https://www.ierigz.waw.pl/prace-badawcze/ranking-300 (data dostępu: 29.07.2014).

przychodów ze sprzedaży niż jednostki z końcówki. Średnio w latach 2007-2012 różnica była ponaddwukrotna (przedsiębiorstwa z pierwszej 50 uzyskały przeciętnie przychody na poziomie 5860 tys. zł, a z ostatniej 50 na poziomie 13043 tys. zł). Można więc uznać, że przedsiębiorstwa, które kończyły „ranking najlepszych przedsiębiorstw rolnych" wykorzystywały efekt skali, co miało swoje pozytywne efekty w łącznej wartości przychodów ze sprzedaży ${ }^{1}$ ). Mimo różnic w potencjale produkcyjnym (mierzonym powierzchnią użytków rolnych, liczbą zatrudnionych i wskaźnikiem bonitacji gleb) nie zaobserwowano wyraźnych różnic w poziomie finansowania aktywów kapitałem własnym. Zarówno przedsiębiorstwa z czołówki, jak i końcówki zestawienia charakteryzowały się poziomem finansowania aktywów kapitałem własnym wynoszącym ok. 60-76\%. Należy uznać, że w wypadku przedsiębiorstw rolniczych jest to dość bezpieczny poziom samofinansowania, chociaż pełniejsza ocena wymagałaby dokładnego zbadania tak struktury aktywów, jak i struktury źródeł ich finansowania ${ }^{2}$. Nieco inaczej prezentowała się sytuacja w wypadku wskaźnika pokrycia zobowiązań nadwyżką finansową. Stwierdzono, że znacznie lepszą sytuacją finansową cechowały się przedsiębiorstwa $\mathrm{z}$ czołówki zestawienia, a poziom nadwyżki finansowej względem zobowiązań był na bardzo wysokim i zadowalającym poziomie.

\footnotetext{
${ }^{1} \mathrm{Z}$ badań autorki wynika, że nie miało to odzwierciedlenia w poziomie wskaźników rentowności sprzedaży, aktywów i kapitału własnego, gdyż wyższe poziomy wskaźników uzyskiwały przedsiębiorstwa z czołówki zestawienia.

2 To nie jest celem obecnego badania.
} 
Uogólniając, można więc stwierdzić, że mniejszy potencjał produkcyjny przedsiębiorstw $\mathrm{z}$ czołówki rankingu miał swoje odzwierciedlenie $\mathrm{w}$ znacznie niższym niż w przedsiębiorstwach z końcówki poziomie przychodów ze sprzedaży, jednak obydwie grupy przedsiębiorstw cechowały się zbliżonym i satysfakcjonującym poziomem finansowania aktywów kapitałem własnym. Wyraźnie lepszą sytuacją finansową charakteryzowały się jednak przedsiębiorstwa z czołówki rankingu, jeśli za punkt odniesienia przyjęto relację nadwyżki finansowej do zobowiązań.

W tabeli 3 zaprezentowano miary charakteryzujące płynność finansową badanych grup przedsiębiorstw. Od lat trwają dyskusje czy przedsiębiorstwa rolnicze powinny charakteryzować się wyższymi poziomami płynności, czy też jest to skutek awersji do ryzyka i ostrożnościowego podejścia przedsiębiorców do kwestii regulowania zobowiązań bieżących. Poza podstawowymi miarami, takimi jak wskaźnik płynności bieżącej i szybkiej, zaprezentowano również wskaźnik generowania gotówki operacyjnej ${ }^{3}$. Stwierdzono, że przedsiębiorstwa z czołówki rankingu cechowały się znacznie wyższymi wskaźnikami płynności bieżącej, co w zestawieniu ze wskaźnikiem pokrycia zobowiązań nadwyżką finansową sugeruje stosunkowo niski poziom zobowiązań. Potwierdza również dotychczasowe wyniki badań, z których wynika, że mniejsze przedsiębiorstwa cechują wyższe wskaźniki płynności, gdyż przedsiębiorcy unikają (w miarę możliwości) obrotu bezgotówkowego i minimalizują zaciąganie zobowiązań. W efekcie daje to bardzo wysoki poziom płynności. Nieco inaczej prezentowała się sytuacja w przedsiębiorstwach z końcówki zestawienia, które to cechowały się znacznie niższymi (chociaż i tak bardzo wysokimi) wskaźnikami płynności bieżącej (chociaż nie uchroniło to tej grupy przedsiębiorstw przed ujemnymi wskaźnikami rentowności sprzedaży we wszystkich badanych latach ${ }^{4}$ ). Podobne zależności zaobserwowano w wypadku wskaźnika płynności szybkiej, którego znacznie wyższe poziomy cechowały przedsiębiorstwa z czołówki zestawienia niż te z końcówki. Częściowe wyjaśnienie tej sytuacji może dać wskaźnik generowania gotówki operacyjnej, który był wielokrotnie wyższy w przedsiębiorstwach z pierwszej 50 . W tej grupie przedsiębiorstw wskaźnik oscylował w granicach $32-42 \%$, a w grupie porównywanej w zakresie zaledwie $8-10 \%$. Różnica jest więc wyraźna i wskazuje na lepszą sytuację płynnościową przedsiębiorstw z czołówki zestawienia.

\footnotetext{
${ }^{3}$ Dane dotyczące tej miary dostępne było dopiero od 2008 roku.

${ }^{4}$ Sprawdzono w odrębnej procedurze badawczej.
} 
Tabela 3

Wybrane miary płynności finansowej przedsiębiorstw rolniczych uczestniczących w „Rankingu 300" w latach 2007-2012 (17. i 83. percentyl)

\begin{tabular}{|c|c|c|c|c|c|c|c|}
\hline \multirow{2}{*}{ Wyszczególnienie } & \multicolumn{7}{c|}{ Dane w latach } \\
\cline { 2 - 7 } & 2007 & 2008 & 2009 & 2010 & 2011 & 2012 \\
\hline \multicolumn{7}{|c|}{ Wskaźnik płynności bieżącej } \\
\hline Przedsięb. - 17. percentyl & 9,40 & 12,06 & 12,24 & 24,28 & 30,39 & 15,05 \\
\hline Przedsięb. - 83. percentyl & 6,95 & 5,06 & 4,78 & 7,12 & 5,31 & 8,46 \\
\hline \multicolumn{7}{|c|}{ Wskaźnik płynności szybkiej } \\
\hline Przedsięb. - 17. percentyl & 5,61 & 5,65 & 6,77 & 17,40 & 20,61 & 8,51 \\
\hline Przedsięb. - 83. percentyl & 3,58 & 2,33 & 2,38 & 1,66 & 3,04 & 5,37 \\
\hline \multicolumn{7}{|c|}{ Wskaźnik generowania gotówki operacyjnej [\%] } \\
\hline Przedsięb. - 17. percentyl & - & - & 32,34 & 38,87 & 38,81 & 42,50 \\
\hline Przedsięb. - 83. percentyl & - & - & 8,78 & 8,73 & 10,67 & 9,88 \\
\hline
\end{tabular}

Źródło: Opracowanie własne na podstawie danych „Rankingu 300” za lata 2007-2012, https://www.ierigz.waw.pl/prace-badawcze/ranking-300 (data dostępu: 29.07.2014).

Na rysunku 1 przedstawiono wykresy ramka-wąsy wskaźników płynności bieżącej badanych grup przedsiębiorstw. Stwierdzono, że grupa przedsiębiorstw z czołówki zestawienia charakteryzuje się znacznie większym zróżnicowaniem poziomów wskaźnika niż grupa przedsiębiorstw z końcówki zestawienia. Oznacza to, że przedsiębiorstwa zajmujące miejsca 1-50 w ,,rankingu najlepszych przedsiębiorstw rolniczych" są grupą znacznie mniej jednorodną, chociaż stosunkowo niewielkie zróżnicowanie poziomów wskaźników płynności bieżącej tej grupy przedsiębiorstw zaobserwowano w 2011 roku. Nie można więc stwierdzić, że przedsiębiorstwa z czołówki rankingu charakteryzowały się określonym - dedykowanym innym przedsiębiorstwom rolniczym - poziomem wskaźników płynności bieżącej. Należy raczej uznać, że nie występował określony (zbliżony w większej grupie podmiotów) poziom płynności, który można byłoby uznać za docelowy. Tak więc w opinii autorki jest to obszar bardzo indywidualny, będący efektem wielu decyzji w każdym przedsiębiorstwie i nie daje podstaw do stwierdzenia, że wysokie wskaźniki płynności w tej grupie przedsiębiorstw można byłoby rekomendować jako te, które zapewniają bezpieczeństwo płynności w przedsiębiorstwach rolniczych. Aby sprawdzić czy podobna sytuacja miała miejsce $\mathrm{w}$ wypadku wskaźników płynności szybkiej, na rysunku 2 przedstawiono wykresy ramka-wąsy dla tej miary. 
12
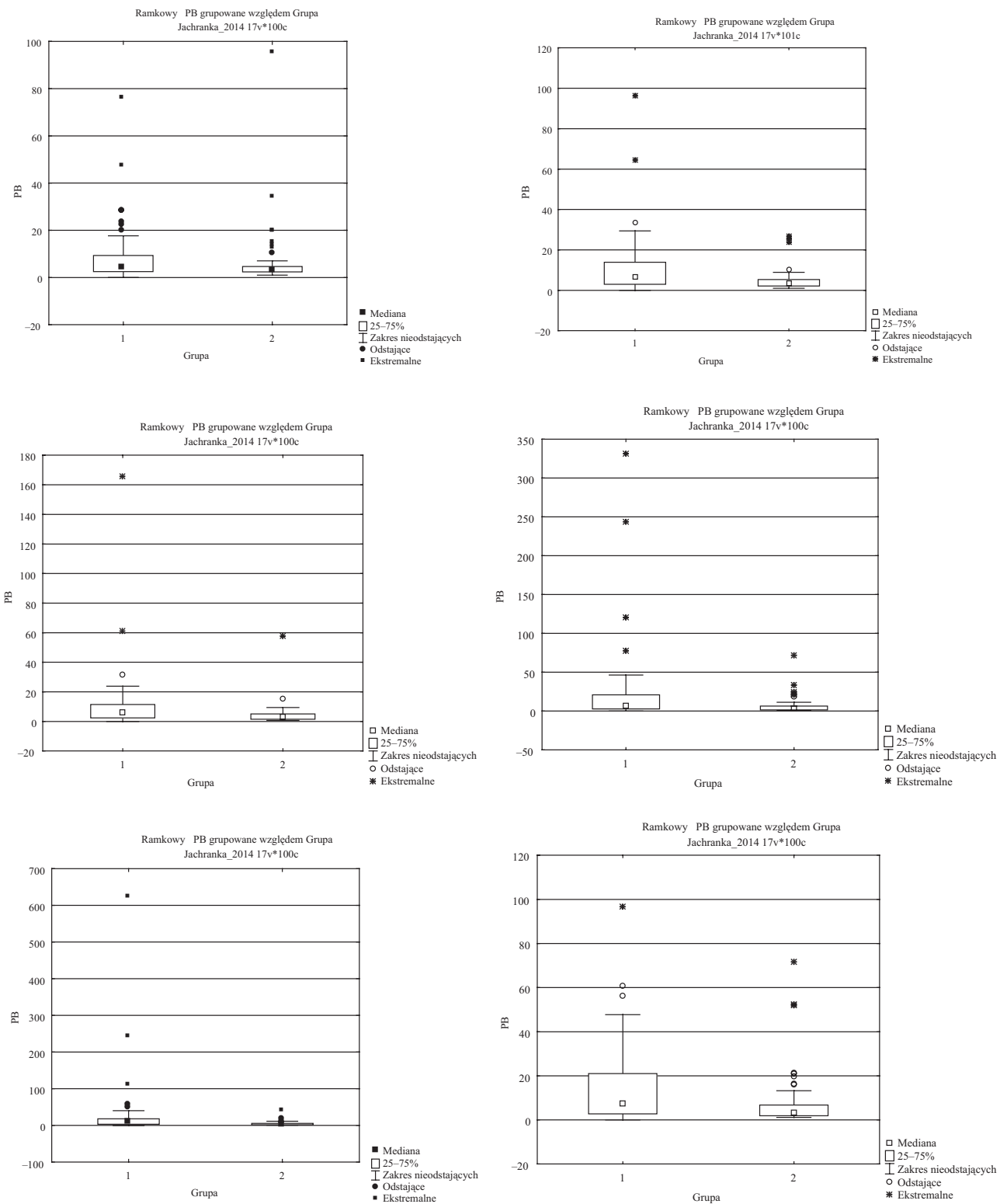

\section{Rysunek 1}

Wykresy ramka-wąsy dla wskaźnika płynności bieżącej w grupie przedsiębiorstw z czołówki i końcówki „Rankingu 300” w latach 2007-2012

Źródło: Opracowanie własne. 

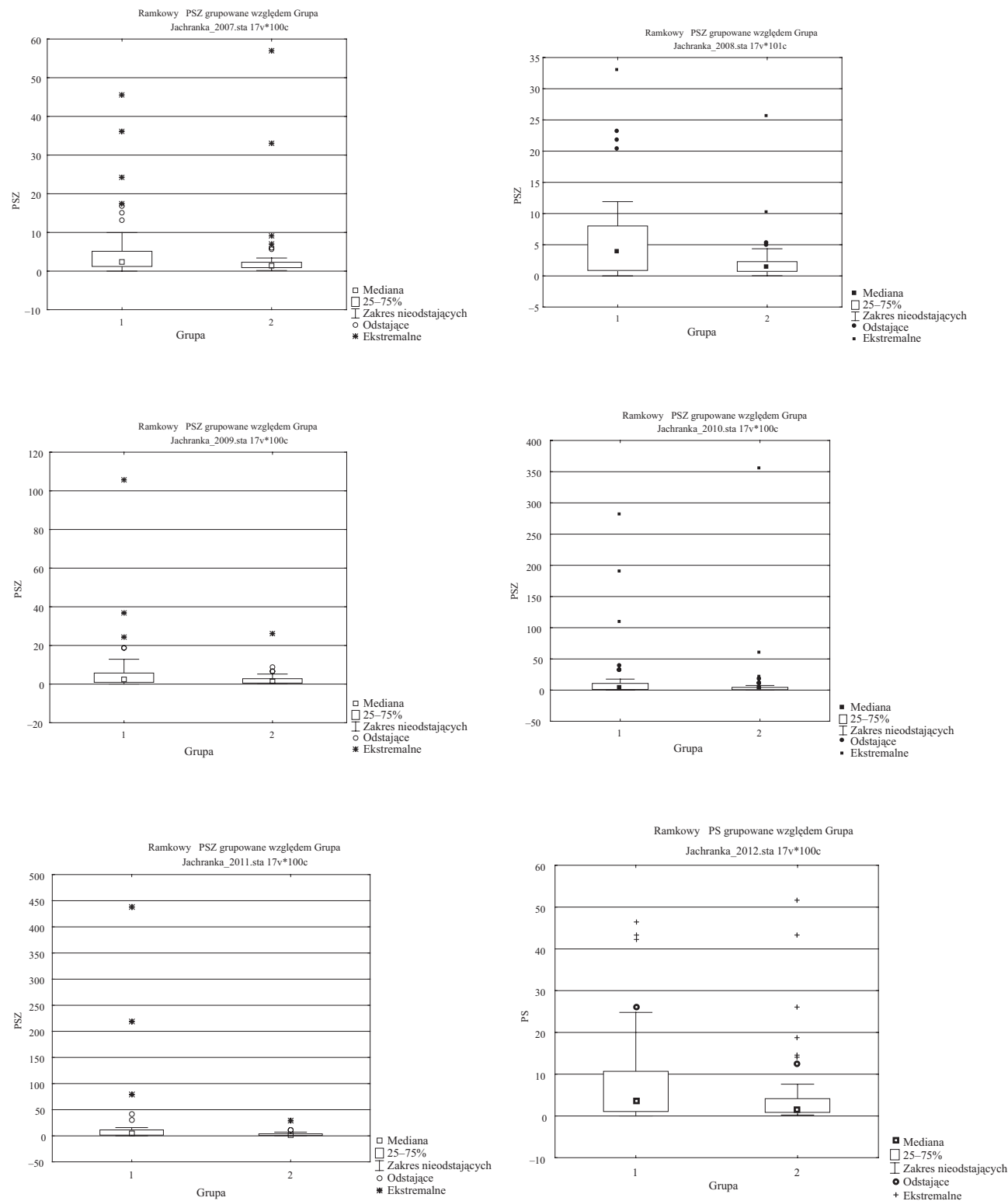

\section{Rysunek 2}

Wykresy ramka-wąsy dla wskaźnika płynności szybkiej w grupie przedsiębiorstw z czołówki i końcówki „Rankingu 300” w latach 2007-2012

Źródło: Opracowanie własne. 
Analizując wykresy ramka-wąsy wskaźników płynności szybkiej stwierdzono, że występowało nieco mniejsze zróżnicowanie wskaźników w badanych grupach $w$ trzech z sześciu badanych lat. Mniejszy rozstęp - szczególnie w grupie przedsiębiorstw z czołówki rankingu - widoczny był w latach 2009-2011, a zatem wskaźniki płynności szybkiej wykazywały nieco mniejsze zróżnicowanie w grupach niż wskaźniki płynności bieżącej. Może być to skutkiem różnych kierunków działalności przedsiębiorstwa, a zatem innych poziomów i typów zapasów. Podobnie jak w wypadku wskaźnika płynności bieżącej, także i wskaźnik płynności szybkiej znajdował się na wyższych poziomach w przedsiębiorstwach z pierwszej 50. zestawienia, jednak był on dość zróżnicowany w obrębie tej grupy, a więc trudno rekomendować jego określony, wyższy poziom, jako ten właściwy i zapewniający bezpieczeństwo płynności.

\section{Podsumowanie i wnioski}

Z przedstawionych badań wynika, że najlepsze przedsiębiorstwa rolnicze w Polsce, które uczestniczą w „Rankingu 300”, charakteryzują się bardzo dobrą sytuacją finansową, zarówno te z czołówki, jak i końcówki zestawienia. Porównywane grupy przedsiębiorstw były zróżnicowane pod względem zasobów (znacznie większe zasoby ziemi i liczby zatrudnionych cechowały przedsiębiorstwa z końcówki zestawienia), jak i ich jakości (wyższe wskaźniki bonitacji gleb charakteryzowały przedsiębiorstwa z czołówki). Skutkiem wyższego poziomu zasobów były zdecydowanie większe przychody ze sprzedaży w przedsiębiorstwach kończących ranking. Obie grupy przedsiębiorstw charakteryzowały się poziomem samofinansowania na zbliżonym i satysfakcjonującym poziomie i była to miara, która ich znacząco nie różnicowała.

Znaczne zróżnicowanie stwierdzono także w zakresie wskaźników płynności, zarówno bieżącej, jak i szybkiej, a przedsiębiorstwa z pierwszej 50 cechowały się znacznie wyższymi wskaźnikami płynności. W ocenie autorki może być to skutkiem tego, że były to przedsiębiorstwa mniejsze, których kierownictwo/ /właściciele - jak wskazują liczne wyniki badań - unika zadłużania, jeśli nie jest to konieczne, a zatem cechują się niższym poziomem zobowiązań i wyższymi wskaźnikami płynności. Dodatkowo, na podkreślenie zasługuje to, że przedsiębiorstwa z czołówki zestawiania cechowały się wyraźnie wyższym poziomem wskaźnika generowania gotówki operacyjnej, co należy uznać za bardzo dobrą cechę tych jednostek. Jednym bowiem z podstawowych obszarów decyzji finansowych jest poszukiwanie możliwości generowania gotówki z podstawowej - a zatem operacyjnej - działalności przedsiębiorstwa. Znacznie gorzej prezentowała się $\mathrm{w}$ tym zakresie sytuacja $\mathrm{w}$ przedsiębiorstwach kończących ranking. 
Niezależnie jednak od miejsca w zestawieniu „Rankingu 300” należy uznać, że zarówno przedsiębiorstwa z czołówki, jak i końcówki zestawienia były w dobrej sytuacji finansowej i utrzymywały wskaźniki płynności na bardzo wysokim poziomie. Miary, które zostały ocenione, dają podstawę do stwierdzenia, że są to przedsiębiorstwa dobrze funkcjonujące, o dobrych perspektywach dalszego funkcjonowania, jednak w przedsiębiorstwach z końcówki rankingu należałoby przywiązywać więcej uwagi w obszarze zdolności do generowania gotówki operacyjnej, aby podstawowa działalność tych podmiotów umożliwiała uzyskiwanie środków pieniężnych tak na bieżącą działalność, jak i na ich rozwój.

\section{Ograniczenia}

Przeprowadzone badania dotyczyły grupy przedsiębiorstw z czołówki i końcówki „Rankingu 300”, a więc zestawienia, w którym przedsiębiorcy rolni biorą udział dobrowolnie. Nie są to więc badania reprezentatywne. W ocenie autorki jest to jednak bardzo cenna baza danych, w której od połowy lat 90 . XX wieku gromadzone są informacje o znaczącej liczbie przedsiębiorstw rolniczych. Przeprowadzone analizy pozwoliły na wykazanie pewnych różnic między grupami przedsiębiorstw rozpoczynającymi i kończącymi zestawienie. W ocenie autorki ich sytuacja finansowa jest dobra, a wskaźniki płynności na zadawalającym, chociaż bardzo wysokim poziomie. Miarą uzupełniającą badanie płynności, która powinna być brana pod uwagę przez przedsiębiorców, jest wskaźnik generowania gotówki operacyjnej, który był dość niski w przedsiębiorstwach z końcówki zestawienia.

Przedstawione wyniki badań należy traktować jako pewien wycinek szerszych analiz, a w ocenie autorki konieczne jest dalsze zgłębianie problematyki sytuacji finansowej i płynności przedsiębiorstw rolniczych, gdyż stanowią one bazę zapewnienia bezpieczeństwa żywnościowego kraju. Zatem należy podkreślić, że są to przedsiębiorstwa, których sytuacja finansowa powinna umożliwiać sprawny przebieg procesów produkcyjnych, inwestycyjnych, a więc i rozwój.

\section{Literatura}

BEREŻNICKA J., 2011: Poziom kapitału obrotowego a możliwości generowania kapitału finansowego w rodzinnych gospodarstwach rolniczych, Roczniki Nauk Rolniczych Seria G, Ekonomika Rolnictwa 98(4), 49-55.

BIENIASZ A., GOŁAŚ Z., 2006: Istota i zróżnicowanie plynności finansowej gospodarstw rolnych, Roczniki Akademii Rolniczej w Poznaniu CCCLXXVII. 
FRANC-DĄBROWSKA J., 2011: Pułapka plynności Keynesa a dylematy oceny płynności przedsiębiorstw rolniczych, Zeszyty Naukowe SGGW - Ekonomika i Organizacja Gospodarki Żywnościowej 91.

MAŃKO S., SOBCZYŃSKI T., SAS R., 2008: Zmiany poziomu zrównoważenia płynności finansowej $w$ gospodarstwach rolniczych UE w latach 1989-2005, Zeszyty Naukowe SGGW - Ekonomika i Organizacja Gospodarki Żywnościowej 64.

PASZKO D., 2010: Zróżnicowanie płynności finansowej na przykładzie wybranych gospodarstw sadowniczych, Zeszyty Naukowe Instytutu Sadownictwa i Kwiaciarstwa im. Szczepana Pieniążka, tom 18.

„Ranking 300” za lata 2007-2012, https://www.ierigz.waw.pl/prace-badawcze/ranking-300, (data dostępu: 29.07.2014).

STEFKO O., 2011: Zróżnicowanie między płynnościq a wypłacalnościa polskich producentów ogrodniczych na tle Unii Europejskiej, Zeszyty Naukowe SGGW - Ekonomika i Organizacja Gospodarki Żywnościowej 90.

SZAFRANIEC-SILUTA E., 2013: Bezpieczeństwo finansowe przedsiębiorstw rolniczych $w$ Polsce - ujęcie porównawcze, Zarządzanie i Finanse - Journal of Management and Finance $2 / 2$.

WASILEWSKI M., GAŁECKA A., 2010: Plynność finansowa gospodarstw rolniczych położonych $w$ województwie lubelskim, Zeszyty Naukowe SGGW - Ekonomika i Organizacja Gospodarki Żywnościowej 82.

ZAWADZKA D., ARDAN R., SZAFRANIEC-SILUTA E., 2011: Ptynność finansowa a rentowność przedsiębiorstw rolnych $w$ Polsce - ujęcie modelowe, Zeszyty Naukowe SGGW - Ekonomika i Organizacja Gospodarki Żywnościowej 88.

\section{Financial liquidity of the best agricultural enterprises in Poland (on the example of enterprises listed in "The Rating of 300")}

\section{Abstract}

The aim of the study was to assess the financial position and liquidity of the best agricultural enterprises in Poland. The study involved 50 companies from the top and 50 from the end of "The Rating of 300". Quite significant differences in the ratios of current liquidity and fast liquidity were found both between and within the groups of enterprises. Both of the groups of companies were characterized by good financial situation. 